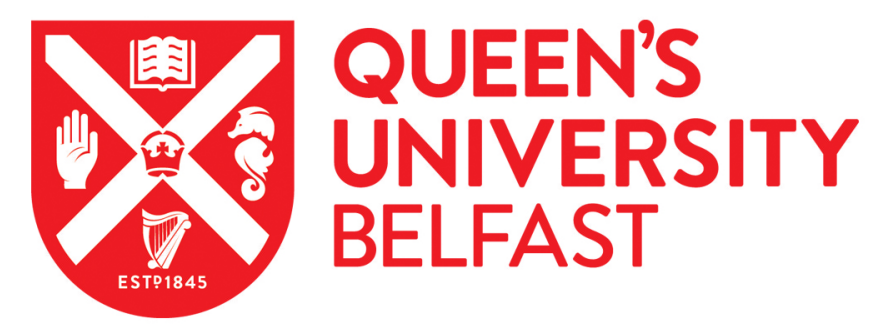

\title{
Controlled fragrance delivery in functionalised ionic liquid-enzyme systems
}

Blesic, M., Gunaratne, H. Q. N., Nockemann, P., McCarron, P., \& Seddon, K. R. (2013). Controlled fragrance delivery in functionalised ionic liquid-enzyme systems. RSC Advances, 3(2), 329-333.

https://doi.org/10.1039/c2ra22500j

\section{Published in:}

RSC Advances

Document Version:

Publisher's PDF, also known as Version of record

Queen's University Belfast - Research Portal:

Link to publication record in Queen's University Belfast Research Portal

\section{Publisher rights}

Copyright The Royal Society of Chemistry 2013. This is an open access Creative Commons Attribution-NonCommercial License (https://creativecommons.org/licenses/by-nc/4.0/), which permits use, distribution and reproduction for non-commercial purposes, provided the author and source are cited.

\section{General rights}

Copyright for the publications made accessible via the Queen's University Belfast Research Portal is retained by the author(s) and / or other copyright owners and it is a condition of accessing these publications that users recognise and abide by the legal requirements associated with these rights.

\section{Take down policy}

The Research Portal is Queen's institutional repository that provides access to Queen's research output. Every effort has been made to ensure that content in the Research Portal does not infringe any person's rights, or applicable UK laws. If you discover content in the Research Portal that you believe breaches copyright or violates any law, please contact openaccess@qub.ac.uk. 
Cite this: RSC Advances, 2013, 3, 329

\section{Controlled fragrance delivery in functionalised ionic liquid-enzyme systems $\uparrow$}

Received 12th October 2012,

Accepted 8th November 2012

DOI: $10.1039 / \mathrm{c} 2 \mathrm{ra} 22500$

www.rsc.org/advances

It is often believed that both ionic liquids and surfactants generally behave as non-specific denaturants of proteins. In this paper, it is shown that amphiphilic ionic liquids bearing a long alkyl chain and a target molecule, where the target molecule is appended via a carboxylic ester functionality, can represent supersubstrates that enable the catalytic activity of an enzyme, even at high concentrations in solution. Menthol has been chosen as the target molecule for slow and controlled fragrance delivery, and it was found that the rate of the menthol release can be controlled by the chemical structure of the ionic liquid. At a more fundamental level, this study offers an insight into the complex hydrophobic, electrostatic, and hydrogen bond interactions between the enzyme and substrate.

The term 'ionic liquid' refers to the liquid state of matter exhibited by salts at, close to, or below $100{ }^{\circ} \mathrm{C}$. Ionic liquids are typically organic salts of which 1,3-dialkylimidazolium salts are archetypes. ${ }^{1,2}$ The majority of papers published emphasise their advantage regarding the numerous combinations of cations and anions, and consequently the possibility of tuning their physical properties. However, only a relatively small number of published articles deal with designed ionic liquids for specific purposes; it is still more common to search for potential applications of the most popular classes of ionic liquids.

The interaction of enzymes with either ionic liquids ${ }^{3-10}$ or surfactants $^{11-13}$ has been the subject of many investigations. Some research groups demonstrated the applicability of ionic liquids as novel media for enzymatic reactions, ${ }^{14,15}$ whereas this contribution demonstrates their applicability as substrates for enzymatic ester hydrolysis. Herein, the enzyme chosen was lipase because of

The QUILL Centre, School of Chemistry and Chemical Engineering, The Queen's University of Belfast, Stranmillis Road, Belfast BT9 5AG, United Kingdom. E-mail:mblesic@chem.polimi.it; quill@qub.ac.uk

$\dagger$ Electronic Supplementary Information (ESI) available: synthesis and characterisation of the ionic liquids $\left({ }^{1} \mathrm{H}\right.$ NMR and ${ }^{13} \mathrm{C}$ NMR spectroscopy, $\mathrm{CNH}$ analysis, melting points), experimental techniques, instrumentation for interfacial tension (IFT), fluorescence, crystallographic data and GC. See DOI: 10.1039/c2ra22500j † Present address: Politecnico di Milano, DCMIC Giulio Natta, NFMLab, I-20131 Milan, Italy. its low cost and availability, robustness, versatility, and activity over a broad range of temperatures and $\mathrm{pH}^{16,17}$ Lipases are commonly incorporated into laundry formulations for triglyceridebased stain removal. ${ }^{18,19}$ They constitute a special category of esterase enzymes which are highly efficient at hydrolysing molecules with carboxylic ester groups. ${ }^{20,21}$ One of the most interesting features of a lipase, which distinguishes it from an esterase, is the abrupt increase in activity upon crossing the solubility boundary of a substrate, i.e. after interface formation. The interfacial activation was also found after passing the point of micellisation of the substrate. ${ }^{22}$

Bearing these facts in mind, the ionic liquids used in this work were synthesised to fulfil the requirements of an enzyme substrate: they have a long alkyl chain capable of aggregating in water (and also contribute to a better adhesion of these ionic liquids to fabrics if used for laundry purposes), and carboxylic ester groups in their structures (Fig. 1 and 2). Although lipase is also active on substrates with a low solubility in water, or an emulsion forming

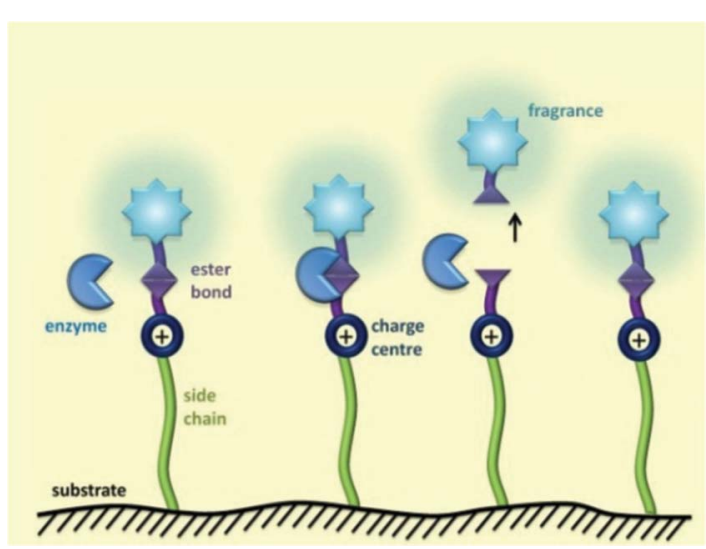

Fig. 1 A pictorial representation of ionic liquid-tagged target molecules anchored to a substrate, and their release mediated by an enzyme. In this work, ionic liquids have been designed and synthesized for fragrance delivery, but the concept can be applied for delivery of other active compounds, including pharmaceuticals, sensors, etc. 


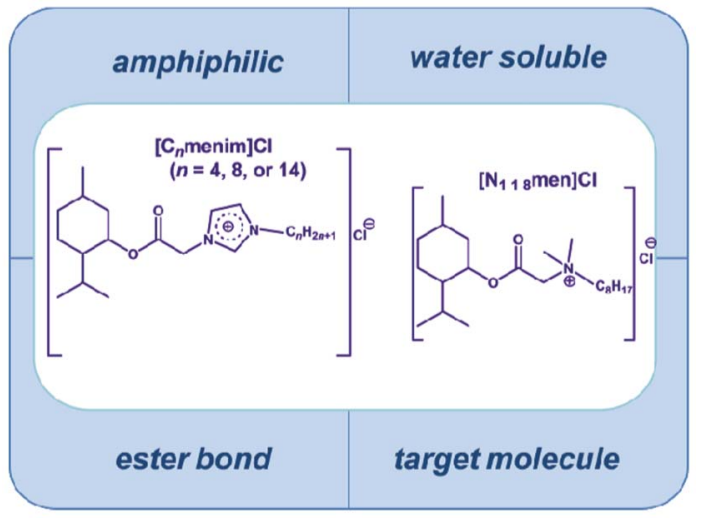

Fig. 2 Rationale for the design of ionic liquids bearing menthyl ester groups for fragrance delivery, $\left[C_{n}\right.$ menim] $\mathrm{Cl}(n=4,8$, or 14$)$, and [ $\mathrm{N}_{1} 1$ smen]Cl.

substrate, micelle-forming systems are preferred since they are thermodynamically stable, easily controlled and defined.

Self-aggregation of the ionic liquids in water over low concentration regimes was studied by surface tension and fluorescence spectroscopy with pyrene as a probe molecule. The surface tension of aqueous solutions of four ionic liquids was measured as a function of concentration. Surfactant aggregation in solution leads to a decrease in the surface tension with increasing concentration, followed by a change to almost constant surface tension as the critical aggregate concentration (CAC) is reached. Data are shown in Fig. 3(a) and Table 1. The surface tension data were used to determine the $\mathrm{CAC}$, from the intersection of a linear extrapolation of the two differing regions. For comparison purposes, the data for the structurally similar ionic liquid family $\left[\mathrm{C}_{n} \operatorname{mim}\right] \mathrm{Cl},(n=4,8$, or 14$)$ are included. ${ }^{23}$ From the CAC values for these two families of ionic liquids, the contribution of the menthyl ester unit to the free energy in the formation of the micellar aggregate was found to be $-\Delta G_{\mathrm{m}}=(8.3$ $\pm 0.5) \mathrm{kJ} \mathrm{mol}^{-1}$ which is approximately equal to the contribution of five methylene units added to a single chain ionic surfactant. ${ }^{24}$ It should be noted that a plateau was found, even for a short chain $\left[\mathrm{C}_{4}\right.$ menim $] \mathrm{Cl}$.
Table 1 Critical aggregate concentration, CAC (in $\mathrm{mM}$ ) of [ $\mathrm{C}_{n}$ menim $] \mathrm{Cl}$ and $\left[C_{n}\right.$ mim $] \mathrm{Cl}_{1}{ }^{23} n=4,8$, or 14 , and [ $\left.\mathrm{N}_{1}{ }_{18} \mathrm{men}\right] \mathrm{Cl}$, measured by interfacial tension, IFT and fluorescence spectroscopy. The experimental errors for both techniques are $\leqslant 10 \%$

\begin{tabular}{lcc}
\hline & \multicolumn{2}{c}{$\mathrm{CAC}$} \\
\cline { 2 - 3 } Ionic liquid & IFT & \\
\hline$\left[\mathrm{C}_{4}\right.$ menim $] \mathrm{Cl}$ & 80 & 130 \\
{$\left[\mathrm{C}_{8}\right.$ menim] } & 8 & 16 \\
{$\left[\mathrm{C}_{14}\right.$ menim $] \mathrm{Cl}$} & 0.13 & 0.11 \\
{$\left[\mathrm{~N}_{1}{ }_{8} \mathrm{men}\right] \mathrm{Cl}$} & 8 & 11 \\
{$\left[\mathrm{C}_{4}\right.$ mim $] \mathrm{Cl}$} & $*$ & $*$ \\
{$\left[\mathrm{C}_{8}\right.$ mim $] \mathrm{Cl}$} & 220 & $*$ \\
{$\left[\mathrm{C}_{14}\right.$ mim $] \mathrm{Cl}$} & 4 & 3 \\
${ }^{*}$ Aggregation was not found. & &
\end{tabular}

Fluorescence spectroscopy, using pyrene as a molecular probe, was used to investigate the polarity of the probe domains in the solutions as a function of the surfactant concentrations. The intensities of the first (I1) and third (I3) vibronic bands in the pyrene emission spectra located around 373 and $384 \mathrm{~nm}$, respectively, were measured and used to determine the ratio $13 /$ I1. The intensity ratio $I 3 / I 1$ varies as a function of the polarity of the pyrene environment and increases with decreasing solvent polarity. ${ }^{25}$ Fig. 3(b) shows the pyrene response (I3/I1) for the aqueous solutions of the salts as a function of concentration. The CAC is determined from the intersection points between that plateau and the descending part of the fluorescence profile (Table 1). The decrease in the CAC of aqueous solutions of $\left[\mathrm{C}_{n}\right.$ menim $] \mathrm{Cl},(n=4,8$, or 14$)$ is a consequence of the increased alkyl chain in the cation. But the presence of the hydrophobic menthyl ester group has a significant effect on the shape of the I3/ $I 1$ curves. In the case of $\left[\mathrm{C}_{14}\right.$ menim $] \mathrm{Cl}$, a change in the slope of the I3/I1 curve, rather than a plateau, was found. It may indicate that the monomers do not form a well-defined aggregate structure immediately. Initially, loose aggregates are formed which grow and form densely packed structures. This is also followed by the formation of closer packed surface monolayers, see Fig. 3(a). Significant hydrophobic contributions from the menthyl ester unit
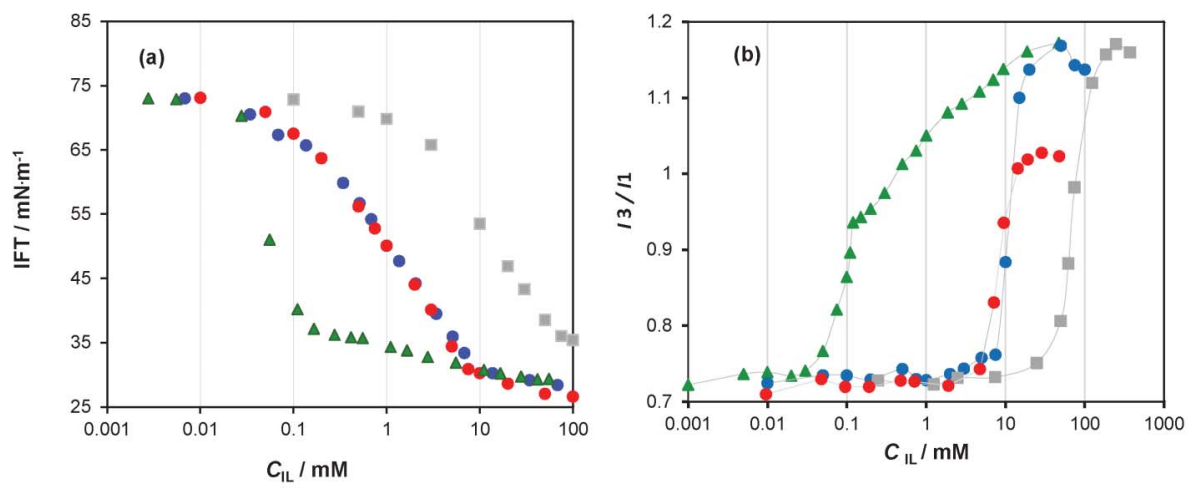

Fig. 3 Monitoring the self-aggregation of four ionic liquids: $\Delta\left[\mathrm{C}_{14}\right.$ menim $] \mathrm{Cl}, \bullet\left[\mathrm{C}_{8}\right.$ menim $] \mathrm{Cl}$, $\boldsymbol{\|}\left[\mathrm{C}_{4}\right.$ menim $] \mathrm{Cl}$, and $\bullet\left[\mathrm{N}_{1}{ }_{1}{ }_{8}\right.$ men $] \mathrm{Cl}$ using two techniques: (a) IFT, (b) fluorescence. 

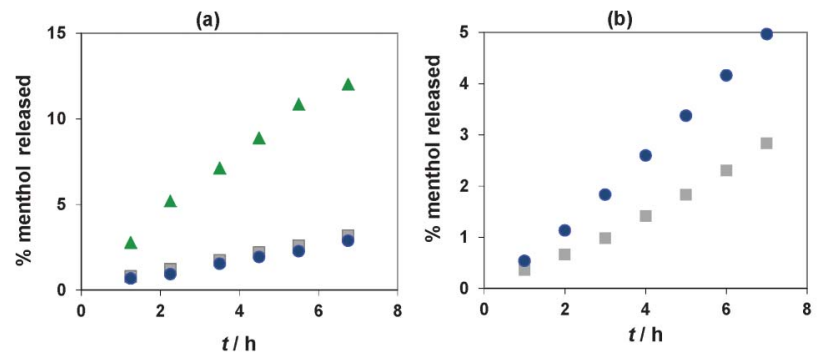

Fig. 4 Rate of the ester hydrolysis measured via menthol release for three ionic liquids: $\Delta\left[\mathrm{C}_{14}\right.$ menim $] \mathrm{Cl}, \bullet\left[\mathrm{C}_{8}\right.$ menim $] \mathrm{Cl}, \boldsymbol{\square}\left[\mathrm{C}_{4}\right.$ menim $] \mathrm{Cl}$. The ionic liquid concentrations were (a) $\mathrm{C}=1 \mathrm{mM}$, and (b) $\mathrm{C}=30 \mathrm{mM}$.

in $\left[\mathrm{C}_{8}\right.$ menim $] \mathrm{Cl}$ and $\left[\mathrm{C}_{4}\right.$ menim $] \mathrm{Cl}$, combined with $\pi-\pi$ stacking interactions of the imidazolium rings are reflected in very high I3/ $I 1$ values that reach 1.2 . Single chain surfactant micellar systems usually reach a plateau in the range $0.75-0.85 .{ }^{26} \mathrm{~A}$ lower $I 3 / I 1$ ratio is found for $\left[\mathrm{N}_{1}{ }_{1}{ }_{8} \mathrm{men}\right] \mathrm{Cl}$ in comparison with $\left[\mathrm{C}_{8}\right.$ menim $] \mathrm{Cl}$, which is expected as a reflection of the loss of the $\pi-\pi$ stacking.

It is known that the structure of cationic surfactants, namely, the charge of the head group, their hydrophobicity and size, have significant effects on enzyme-surfactant interactions. ${ }^{27}$ In this study, it was necessary to elucidate whether, and to what extent, the different structures, hydrophobicities and morphologies of the aggregates affect the enzyme activity, keeping in mind that the binding of an enzyme to a substrate involves hydrophobic and electrostatic interactions, and H-bonds.

The results of the enzyme hydrolysis of the three ionic liquids $\left[\mathrm{C}_{14}\right.$ menim $] \mathrm{Cl},\left[\mathrm{C}_{8}\right.$ menim $] \mathrm{Cl},\left[\mathrm{C}_{4}\right.$ menim $] \mathrm{Cl}$ at $\mathrm{pH} 7.5$ are presented in Fig. 4. In the first experiment the concentration of the ionic liquids was $1 \mathrm{mM}$, Fig. 4(a). It was expected that the two ionic liquids $\left[\mathrm{C}_{8}\right.$ menim $] \mathrm{Cl}$ and $\left[\mathrm{C}_{4}\right.$ menim $] \mathrm{Cl}$ at this low concentration would be in a free monomeric form, while $\left[\mathrm{C}_{14}\right.$ menim $] \mathrm{Cl}$ would be in an aggregated form. It is obvious that the enzyme activity measured by the menthol release is slow and almost equal for $\left[\mathrm{C}_{8}\right.$ menim $] \mathrm{Cl}$ and $\left[\mathrm{C}_{4}\right.$ menim $] \mathrm{Cl}$, but significantly higher for $\left[\mathrm{C}_{14}\right.$ menim $] \mathrm{Cl}$. In the second experiment, Fig. $4(\mathrm{~b})$, the chosen concentration of the ionic liquids was $30 \mathrm{mM}$, at which concentration $\left[\mathrm{C}_{8}\right.$ menim $] \mathrm{Cl}$ is in a micellar form, while $\left[\mathrm{C}_{4}\right.$ menim $] \mathrm{Cl}$ should remain in the monomeric form. The menthol release found for $\left[\mathrm{C}_{4}\right.$ menim $] \mathrm{Cl}$ was the same as obtained for the lower concentration $(1 \mathrm{mM})$, but the menthol release from $\left[\mathrm{C}_{8}\right.$ menim $] \mathrm{Cl}$ was twice that of $\left[\mathrm{C}_{4}\right.$ menim $] \mathrm{Cl}$.

Data for $\left[\mathrm{C}_{14}\right.$ menim]Cl could not be obtained in this higher concentration range because of phase separation (the presence of a phosphate buffer lowered the solubility). As a consequence, the rate of menthol release was high, but the reproducibility very low. This system can be used when a high conversion of a hydrolysis process is required, but it is not suitable for the purpose of slow and controlled release.

The menthol release was also measured for two ionic liquids with a similar hydrophobicity and surface behaviour, $\left[\mathrm{C}_{8}\right.$ menim] $\mathrm{Cl}$, and $\left[\mathrm{N}_{1} 1{ }_{8} \mathrm{men}\right] \mathrm{Cl}$, as a function of concentration and time (Fig. 5(a)). This figure clearly shows that the enzyme has a much higher activity in the presence of $\left[\mathrm{C}_{8}\right.$ menim $] \mathrm{Cl}$ than it does in the presence of $\left[\begin{array}{lll}\mathrm{N}_{1} & 1 & 8\end{array}\right.$ $\left[\mathrm{N}_{1}{ }_{1}{ }_{8} \mathrm{men}\right] \mathrm{Cl}$ is a much weaker hydrogen-bond donor than those ionic liquids based on imidazolium rings. This is clearly shown in Fig. 6. It is known that hydrogen-bond forming compounds interact with amino acid residues localized on a lid that controls entry to the active site, changing its conformation into catalytically more favourable positions. ${ }^{28}$ Moreover, the different distributions of positive charge within the imidazolium ring and in the
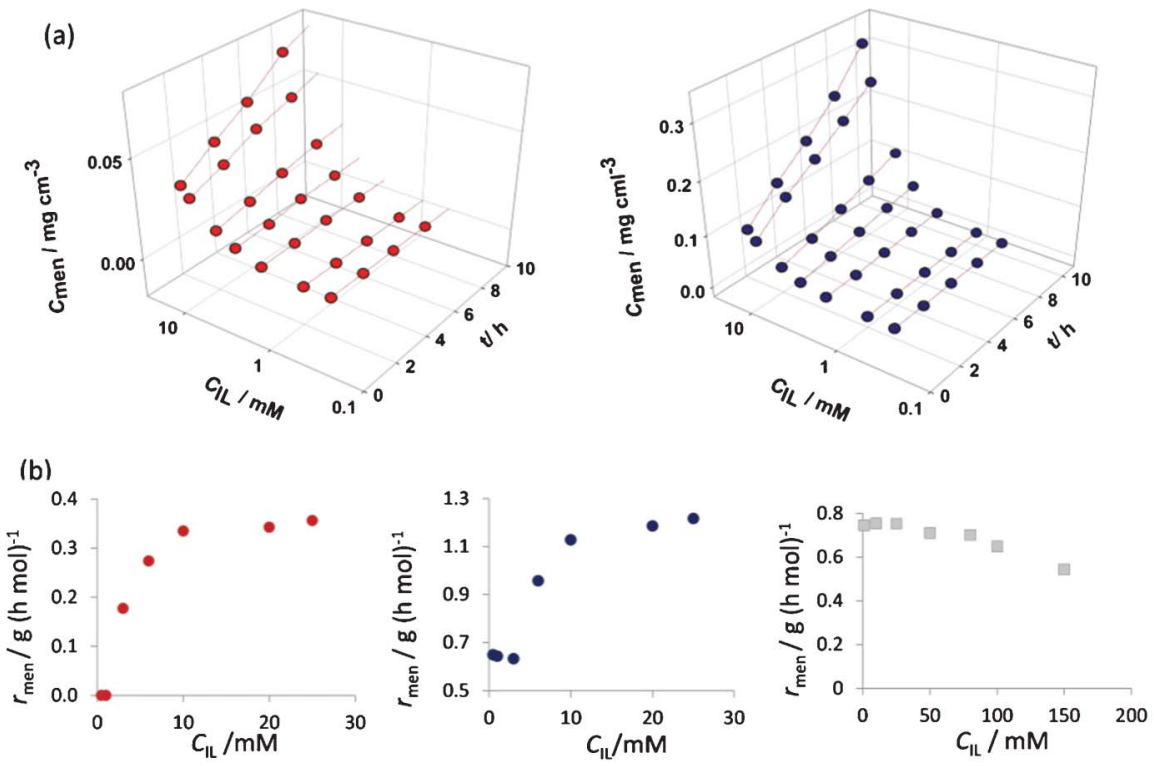

Fig. 5 (a) Menthol release $\left(\mathrm{mg} \mathrm{cm}^{-3}\right)$, and (b) the initial rate of the menthyl ester hydrolysis $\mathrm{r}_{\text {men }}\left[\mathrm{g}(\mathrm{h} \mathrm{mol})^{-1}\right]$ for three ionic liquids: $\mathbf{a}\left[\mathrm{C}_{4} \mathrm{menim}\right] \mathrm{Cl}$, $\left[\mathrm{C}_{8} \mathrm{menim}\right] \mathrm{Cl}$, and $\bullet$

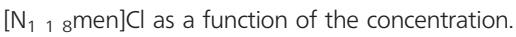




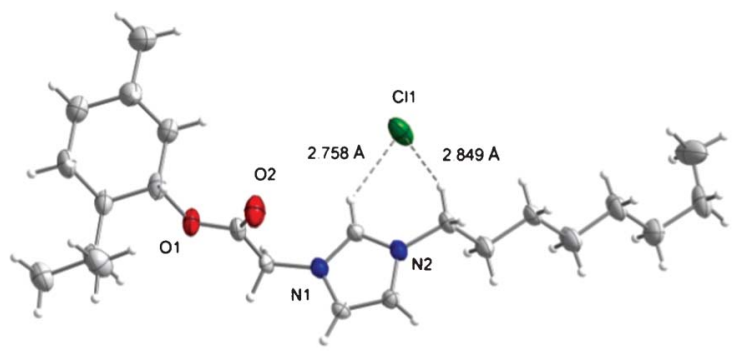

Fig. 6 Structure of a discrete ion pair of $\left[\mathrm{C}_{8}\right.$ menim $] \mathrm{Cl}$, showing hydrogen-bonding interactions between the cation and anion.

$\left[\begin{array}{lll}\mathrm{N}_{1} & 1 & \end{array}\right.$ micellar aggregates that could affect the electrostatic interactions between the charged part of the enzyme and the micellar substrates.

In order to clarify if there is any interfacial activation present after passing the point of micellisation of the substrate, the initial rates of ester hydrolysis are measured and shown in Fig. 5(b) as a function of concentration. Clearly, $\left[\mathrm{N}_{1}{ }_{8} \mathrm{men}\right] \mathrm{Cl}$ is not a suitable substrate for the enzyme and the rate of hydrolysis is much lower compared to the other two ionic liquids, $\left[\mathrm{C}_{4}\right.$ menim $] \mathrm{Cl}$ and $\left[\mathrm{C}_{8}\right.$ menim] Cl. The rate of hydrolysis of $\left[\mathrm{N}_{1}{ }_{1}{ }_{8} \mathrm{men}\right] \mathrm{Cl}$ is increases and reaches a low constant value of $0.3 \mathrm{~g}(\mathrm{~h} \mathrm{~mol})^{-1}$. In practical terms, this value of the menthol release could not be detected by smell, contrary to the case of menthol release from imidazolium based ionic liquids. No discontinuity around the CAC has been found. In the case of $\left[\mathrm{C}_{8}\right.$ menim $] \mathrm{Cl}$, two regions were found; one at a low concentration, probably corresponding to the free monomeric form of the substrate with an initial rate of $0.7 \mathrm{~g}(\mathrm{~h} \mathrm{~mol})^{-1}$, and the other region with an initial rate of $1.2 \mathrm{~g} \mathrm{(h} \mathrm{mol})^{-1}$ was found above $10 \mathrm{mM}$, corresponding to the aggregate form. The break point was found at $c a .5 \mathrm{mM}$. This relatively small change in the menthol release during the micellisation is in agreement with the fact that highly stereospecific lipase B from Candida Antarctica does not have a prominent interfacial activation on supersubstrates,${ }^{29}$ although some changes of the lid structure of the enzyme take place ${ }^{30}$ at the water-oil interface that can affect its catalytic activity. In contrast, $\left[\mathrm{C}_{4}\right.$ menim $] \mathrm{Cl}$ shows no break point. The initial rate of menthol release for $\left[\mathrm{C}_{4}\right.$ menim $] \mathrm{Cl}$ is $0.7 \mathrm{~g}$ (h $\mathrm{mol})^{-1}$ and is equal to the rate found for the free monomer in the case of $\left[\mathrm{C}_{8}\right.$ menim]Cl. This can also be noticed in Fig. 4. It might mean that the short alkyl chain $\left[\mathrm{C}_{4}\right.$ menim $] \mathrm{Cl}$ cannot provide enough hydrophobicity in the interaction with the lipase which would lead to the opening of the lipase lid which covers the active centre. $^{17}$

\section{Conclusions}

We have demonstrated that a set of carefully designed substrates with 'fragrant appendages' activate an enzyme, leading to the controlled release of fragrances. These observations have significance for applications in the detergent and fragrance industries, as well as for the timed release of pharmaceuticals.

\section{Acknowledgements}

The authors wish to thank Dr Tom Moody from Almac Sciences, Belfast, for the gift of lipase B from Candida Antarctica and general advice. The EPSRC UK National Crystallography Service (NCS) is acknowledged for crystal data collection. ${ }^{31}$

\section{References}

1 M. Freemantle, An Introduction to Ionic Liquids, RSC Publishing, Cambridge, 2009.

2 P. Wasserscheid and T. Welton, Ionic Liquids in Synthesis, Wiley VCH, Weinheim, 2nd edn, 2007.

3 S. G. Cull, J. D. Holbrey, V. Vargas-Mora, K. R. Seddon and G. J. Lye, Biotechnol. Bioeng., 2000, 69, 227.

4 R. M. Lau, F. van Rantwijk, K. R. Seddon and R. A. Sheldon, Org. Lett., 2000, 2, 4189.

5 T. Maruyama, H. Yamamura, T. Kotani, N. Kamiya and M. Goto, Org. Biomol. Chem., 2004, 2, 1239.

6 F. van Rantwijk, R. M. Lau and R. A. Sheldon, Trends Biotechnol., 2003, 21, 131.

7 F. van Rantwijk and R. A. Sheldon, Chem. Rev., 2007, 107, 2757.

8 H. Zhao, J. Chem. Technol. Biotechnol., 2010, 85, 891.

9 H. Zhao, G. A. Baker, Z. Y. Song, O. Olubajo, T. Crittle and D. Peters, Green Chem., 2008, 10, 696.

10 H. Zhao, C. L. Jones and J. V. Cowins, Green Chem., 2009, 11, 1128.

11 M. A. Biasutti, E. B. Abuin, J. J. Silber, N. M. Correa and E. A. Lissi, Adv. Colloid Interface Sci., 2008, 136, 1.

12 D. N. Rubingh, Curr. Opin. Colloid Interface Sci., 1996, 1, 598.

13 G. Savelli, N. Spreti and P. D. Profio, Curr. Opin. Colloid Interface Sci., 2000, 5, 111.

14 T. Itoh, E. Akasaki, K. Kudo and S. Shirakami, Chem. Lett., 2001, 262.

15 S. H. Schofer, N. Kaftzik, P. Wasserscheid and U. Kragl, Chem. Commun., 2001, 425.

16 E. N. Vulfson, in Lipases: Their Structure, Biochemistry and Application, ed. P. Woolley and S. B. Petersen, Cambridge University Press, Cambridge, 1994.

17 M. Kapoor and M. N. Gupta, Process Biochem., 2012, 47, 555.

18 F. E. Hardy and A. P. Struillou, EP 0752465 A1, 1987.

19 E. Smulders, W. Rähse and G. Jakobi, Laundry detergents, WileyVCH, Weinheim, 2002.

20 S. P. Colowick, in Lipases, Part B, Enzyme Characterization and Utilization, ed. B. Rubin and E. A. Dennis, Academic Press, New York, 1997.

21 R. D. Schmid and R. Verger, Angew. Chem., Int. Ed., 1998, 37, 1608.

22 D. N. Rubingh and M. Bauer, in Lipase Catalysis of Reactions in Mixed Micelles, ed. P. M. Holland and D. N. Rubingh, ACS Symposium Series, Washington, 1992, 501, p. 210.

23 M. Blesic, M. H. Marques, N. V. Plechkova, K. R. Seddon, L. P. N. Rebelo and A. Lopes, Green Chem., 2007, 9, 481.

24 D. F. Evans and H. Wennerstrom, The Colloidal Domain: Where Physics, Chemistry, Biology and Technology Meet, VCH, New York, 1994.

25 R. Zana, Surfactant Solutions: New Methods of Investigation, Marcel Dekker, New York, 1986.

26 K. Kalyanasundaram and J. K. Thomas, J. Phys. Chem., 1976, 80, 1462. 
27 N. Spreti, F. Alfani, M. Cantarella, F. D’Amico, R. Germani and G. Savelli, J. Mol. Catal. B: Enzym., 1999, 6, 99.

28 K. E. Jaeger, B. W. Dijkstra and M. T. Reetz, Annu. Rev. Microbiol., 1999, 53, 315.
29 J. Uppenberg, M. T. Hansen, S. Patkar and T. A. Jones, Structure, 1994, 2, 293.

30 M. R. Ganjalikhany, B. Ranjbar, A. H. Taghavi and T. T. Moghadam, PLoS One, 2012, 7, e40327.

31 S. J. Coles and P. A. Gale, Chem. Sci., 2012, 3, 683. 